\title{
Review on Effect of Different Irrigation Method on Water Use Efficiency, Yield Productivity and Nitrogen Application
}

\author{
Dessie Gieta Amare \\ Department of Natural Resources Management, Debre Markos University, Ethiopia; P.O Box: 18
}

\begin{abstract}
From these investigation I have been reviewed different conclusions raised by investigators depend on deferent parameters and irrigation method. From the study the parameter taken under consideration are crop morphological characters (plant height, stem girth, cobs, fruit per plant, and leaves per plant e.tc), yield ( $\mathrm{kgha}^{-1}$ ), water productivity $\left(\mathrm{kgha}^{-1}\right)$ and water use efficiency. The study applies different irrigation method to compare its crop morphological characters (plant height, stem girth, cobs, fruit per plant, and leaves per plant e.tc), yield (kgha-1), water productivity $\left(\mathrm{kgha}^{-1}\right)$ and water use efficiency these irrigation method are convention surface irrigation, furrow irrigation, double ridge furrow irrigation, sprinkler irrigation, surface drip irrigation (SDI), subsurface drip irrigation (SSDI) and drip irrigation under different pipeline. In these literature I have been recommend than first yield and growth parameters of the crop depend on the fertility of the soil, chemical fertilizer and physical properties of the rather than irrigation method, therefore, the researchers should be consider these factors. Secondly Water productivity and water use efficiency also depend on soil physical properties, environmental condition, and conveyance system of irrigation and cropping season in addition to irrigation method.
\end{abstract}

Keywords: yield, irrigation, productivity, crop

DOI: $10.7176 / \mathrm{JBAH} / 10-8-01$

Publication date: April $30^{\text {th }} 2020$

\section{Introduction}

Agriculture sector is projected to increase production over the years which will have need of more water resources for irrigation (Sauer et al., 2010). Fresh water availability varies around the world making water scarcity a regional, local, and global issue (Rosegrant, 1997). Water used for agricultural purposes accounts for more than $70 \%$ of the total global water use making agriculture the largest user of freshwater resources .. The efficiency of water used for agriculture globally is relatively low with over $50 \%$ of the water being lost (Bittelli, 2010). North America and Latin America have the highest amount of water available unlike other countries including Africa, Asia, and Europe where water scarcity is a growing problem (Rosegrant, 1997). By the year 2025, scientist predict that there will be 46 to 52 countries that will not have a sufficient amount of water resources available (Rosegrant, 1997). With growing demands on an increasingly scarce supply, water should be recognized as a scarce and important resource that must be regulated and managed judiciously. Efficient water management is a critical factor to maintain a successful crop production system. A low crop yield due to inadequate irrigation is unacceptable to farmers and they often address this by over irrigating crops (Knox et al., 2012). Over irrigating has negative environmental impacts including the leaching of nutrients into groundwater, loss of soil by erosion into rivers and streams and eventually finding its way to the ocean (Brady and Weil, 2010), and a waste of precious fresh water resources.

\section{Objectives}

To review the effect of water application method on the water use efficiency

To review the effect of irrigation method on the yield productivity

To review the effect of irrigation method on fertilizer application efficiency

To compare the productivity of water application method on water use and crop yield

\section{Literature Review}

\subsection{Yield and Water Productivity of Vegetable Production under Drip and Furrow Irrigation}

Water and yield productivity is mainly depend on many factors among these factor method of application of water is among them. There are three categories of water application of water for the growth of the crop these are gravity irrigation, pressurized irrigation and subsurface irrigation. These three irrigation method is not have equal water use efficiency and crop productivity. Pressurized irrigation also categorized in to two these are drip and sprinkler irrigation. In these review I have been review the yield and water productivity of vegetable production under drip and furrow irrigation. In the investigation of this study an experiment was carried out on evaluation of drip and furrow irrigation methods in participatory mode at the farmer's field with an aim to develop understanding about potential benefits of drip irrigation system among the tribal farming community of the eastern plateau and hill region. Comparative assessment in terms of yield gain and water productivity (WP) was conducted for tomato, potato, cauliflower, French bean and pea cultivated in the farmers' fields at Saraitoli village of Ranchi district of Jharkhand. The study shown that, for the selected vegetables, adoption of drip irrigation improved the yields in 
the range of 38.2 to $65.8 \%$ over furrow irrigation with highest yield increase in case of pea $(65.8 \%)$ and tomato $(58.7 \%)$. Drip irrigation consistently recorded higher water productivity (WP) with more than five folds increase in case of potato and cauliflower. The average WP was higher under drip irrigation $(6.89 \mathrm{~kg} \mathrm{~m}-3)$ as compared to furrow method (1.31 kg m-3). (B. K. JHA et al, 2017)

Table: 2.1. Yield and water productivity of different vegetable ((B. K. JHA et al, 2017)

\begin{tabular}{|c|c|c|c|c|c|}
\hline \multirow[t]{2}{*}{ Crops } & \multicolumn{2}{|c|}{ Yield $\left(\mathrm{qha}^{-1}\right)$} & \multirow[t]{2}{*}{$\begin{array}{l}\text { Percent Yield Increase } \\
\text { Over Furrow method }\end{array}$} & \multicolumn{2}{|c|}{ Water Productivity $\left(\mathrm{kgm}^{-3}\right.$} \\
\hline & Drip & Furrow & & Drip & Furrow \\
\hline Tomato & 250.0 & 157.5 & 58.7 & 13.70 & 2.86 \\
\hline Potato & 186.3 & 134.8 & 38.2 & 7.94 & 1.17 \\
\hline Cauliflower & 198.9 & 126.1 & 57.7 & 8.89 & 1.28 \\
\hline French bean & 71.2 & 51.2 & 39.1 & 2.96 & 0.83 \\
\hline Pea & 52.7 & 31.8 & 65.8 & 0.97 & 0.42 \\
\hline
\end{tabular}

\subsection{Effect of Different Irrigation Intervals on Water Saving, Water Productivity and Grain Yield of Maize under the double ridge-furrow}

Surface irrigation is the traditional irrigation method applied though gravity without any pressure. Surface irrigation is one of common irrigation method and less labor and less skill man power requirement irrigation method. Surface irrigation categorizes in to furrow, border and check basin. Furrow irrigation is one of surface irrigation method that the application of water through confined channel known as furrow. Furrow irrigation can be conventional ridge furrow and double ridge furrow irrigation. In these review mainly focused on effect of different irrigation intervals on water saving, water productivity and grain yield of maize under the double ridgefurrow. The double ridge-furrow planting technique (DRFI) uses a practical way to reduce the applied water quantities. The researchers field experiments were carried out in 2010 and 2011 crop (maize) growth periods to study the effects of DRFI with two irrigation intervals - 7 days and 14 days - on maize ${ }^{\text {yield }}$, water saving and water productivity compared with the conventional ridged-furrow planting technique (RFI) with irrigation at 14-day intervals. Plant height, 100-kernel weight and grain yield (GY) were differently affected by RFI14, DRFI 7 and DRFI $_{14}$ treatments Table 2.2. The highest plant height and 100-kernel weight were recorded with $\mathrm{DRF}_{\mathrm{I}}$ in both seasons, whereas the lowest values were recorded with DRFI14. The $\mathrm{DRF}_{17}$ treatment resulted in the highest grain yield, which reached $7164 \mathrm{~kg} \mathrm{ha}^{-1}$ (mean over two seasons), whereas the $\mathrm{DRFI}_{14}$ treatment exhibited the lowest grain yield, which reached $5408 \mathrm{~kg} \mathrm{ha}^{-1}$ (mean over two seasons). The reduced plant height and 100-kernel weight were the main reasons for decreased grain yield as shown in Table 2.2. Grain yield with the conventional RFI $\mathrm{R}_{14}$ treatment was found to be higher than that obtained from the DRFI 14 treatment, which reached $6355 \mathrm{~kg} \mathrm{ha}^{-1}$ (mean over two seasons). The $\mathrm{DRFI}_{7}$ treatment proved more effective in increasing grain yield by $13 \%$ (mean over two seasons) compared to the conventional $\mathrm{RFI}_{14}$ treatment (A. E. El-Halim AND U. E. Abd El-Razek, 2013)

Table: 2.2. Plant height, 100-kemel weight, and grain yield of maize as affected by irrigation treatment in the two season of 2010/2011 ((A. E. El-Halim AND U. E. Abd El-Razek, 2013)

\begin{tabular}{|c|c|c|c|c|}
\hline Treatment & Plant height (m) & $\begin{array}{l}\text { 100-kemel weight } \\
\text { (g) }\end{array}$ & $\begin{array}{l}\text { Grain yield } \\
\left(\mathrm{kgha}^{-1}\right)\end{array}$ & $\begin{array}{c}\text { Increase or decrease of GY } \\
(\%)\end{array}$ \\
\hline \multicolumn{5}{|l|}{ Season, 2010} \\
\hline $\mathrm{RFI}_{14}$ & $2.66 \mathrm{~b}$ & $32.68 \mathrm{~b}$ & $6505 \mathrm{~b}$ & \\
\hline $\mathrm{DRFI}_{7}$ & $2.96 \mathrm{a}$ & $36.93 \mathrm{a}$ & $7133 \mathrm{a}$ & 13.13 \\
\hline $\mathrm{DRFI}_{14}$ & $1.91 \mathrm{c}$ & $26.80 \mathrm{c}$ & $5355 \mathrm{c}$ & 15.07 \\
\hline \multicolumn{5}{|l|}{ Season, 2011} \\
\hline $\mathrm{RFI}_{14}$ & $2.7 \mathrm{~b}$ & $33.21 \mathrm{~b}$ & $6405 \mathrm{~b}$ & \\
\hline $\mathrm{DRFI}_{7}$ & $2.98 \mathrm{a}$ & $37.25 \mathrm{a}$ & $7195 \mathrm{a}$ & 12.33 \\
\hline $\mathrm{DRFI}_{4}$ & $1.95 \mathrm{c}$ & $27.32 \mathrm{c}$ & $5460 \mathrm{c}$ & 14.75 \\
\hline
\end{tabular}

NOTE: $\mathrm{RFI}_{14}$, Ridge furrow irrigation with 14-day interval; $\mathrm{DRFI}_{7}$, Double Ridge furrow irrigation with 7-day interval; $\mathrm{DRFI}_{14}$, Double Ridge furrow irrigation with 14-day interval;

Total applied irrigation water (Aw) was significantly affected by irrigation treatments (Table 2.3). In the first and second seasons, applied irrigation water amounted to 8500 and $9100 \mathrm{~m}^{3} \mathrm{ha}^{-1}$, respectively, for the conventional $\mathrm{RFI}_{14}$ treatment, followed by 7800 and $8300 \mathrm{~m}^{3} \mathrm{ha}^{-1}$, respectively, for the DRFI7 treatment, whereas it amounted to 4900 and $5300 \mathrm{~m}^{3} \mathrm{ha}^{-1}$ for the $\mathrm{DRFI}_{14}$ treatment, respectively. Clearly, the conventional $\mathrm{RFI}_{14}$ treatment required considerably more Aw than the double ridged-furrow treatments. Based on the greater amount of water saving with higher production and hence higher water productivity, it seems that planting maize in double ridge-furrow, where the water was applied at 7-day intervals (A. E. El-Halim AND U. E. Abd El-Razek, 2013) 
Table: 2.3. Total applied water (Aw), water save (Ws), water productivity (Wp) and increasing Wp as affected by irrigation treatments in the two seasons of 2010/2011 (A. E. El-Halim AND U. E. Abd El-Razek, 2013)

\begin{tabular}{|c|c|c|c|c|c|c|}
\hline \multirow[t]{2}{*}{ Treatment } & \multicolumn{2}{|c|}{ Aw } & \multicolumn{2}{|c|}{ Ws } & \multirow[t]{2}{*}{$\mathrm{Wp} \mathrm{kgm}^{-3}$} & \multirow[t]{2}{*}{ Increasing of $\mathrm{Wp} \%$} \\
\hline & $\mathrm{mm}$ & $\mathrm{m}^{3} \mathrm{ha}^{-1}$ & $\mathrm{~m}^{3} \mathrm{ha}^{-1}$ & $\%$ & & \\
\hline \multicolumn{7}{|l|}{ Season, 2010} \\
\hline RFI14 & $850 \mathrm{a}$ & 8500 & & & $0.74 \mathrm{c}$ & \\
\hline DRFI7 & $780 \mathrm{~b}$ & 7800 & 700 & 8.24 & $0.91 \mathrm{~b}$ & 23.29 \\
\hline DRFI14 & $490 \mathrm{c}$ & 4900 & 3600 & 42.35 & $1.09 \mathrm{a}$ & 47.33 \\
\hline \multicolumn{7}{|l|}{ Season , 2011} \\
\hline RFI14 & $910 \mathrm{a}$ & 9100 & & & $0.70 \mathrm{c}$ & \\
\hline DRFI7 & $830 \mathrm{~b}$ & 8300 & 800 & 8.79 & $0.87 \mathrm{~b}$ & 23.16 \\
\hline DRFI14 & $530 \mathrm{c}$ & 5300 & 3800 & 41.76 & $1.03 \mathrm{a}$ & 46.37 \\
\hline
\end{tabular}

NOTE: $\mathrm{RFI}_{14}$, Ridge furrow irrigation with 14-day interval; $\mathrm{DRFI}_{7}$, Double Ridge furrow irrigation with 7-day interval; $\mathrm{DRFI}_{14}$, Double Ridge furrow irrigation with 14-day interval;

\subsection{Effect of Irrigation Methods and Plastic Mulch on Yield and Crop Water Productivity of Okra.}

These review focused on effect of irrigation methods and plastic mulch on yield and crop water productivity of Okra. The researchers carried out afield experiment during 2014-15, to observe the efficiency of irrigation methods and plastic mulch on the yield and crop productivity of Okra. Okra seeds (cv. Subzpari) were grown on ridges with plastic under two different irrigation methods (Every Furrow Irrigation (EFI) and Alternate Furrow Irrigation (AFI)). The soil physical properties of ridges being affected by plastic mulched were analyzed before sowing and after harvesting. The results shown that dry density of soil decreased by $0.03 \mathrm{~g} \mathrm{~cm}^{-3}$ and $0.04 \mathrm{~g} \mathrm{~cm}^{-3}$ for AFI and EFI methods, respectively. The dry density of the soil samples before sowing and after harvesting is presented in Table 2. It indicated that the dry density of soil samples before sowing was same $\left(1.28 \mathrm{~g} \mathrm{~cm}^{-3}\right)$ under EFI and AFI methods, which slightly increased from $1.28 \mathrm{~g} \mathrm{~cm}^{-3}$ to $1.32 \mathrm{~g} \mathrm{~cm}^{-3}$ under EFI and from $1.28 \mathrm{~g} \mathrm{~cm}^{-3}$ to $1.30 \mathrm{~g} \mathrm{~cm}^{-3}$ under AFI. However, with the plastic mulched ridges, the soil dry density slightly decreased from $1.25 \mathrm{~g} \mathrm{~cm}^{-3}$ to $1.22 \mathrm{~g} \mathrm{~cm}^{-3}$ under EFI and from $1.23 \mathrm{~g} \mathrm{~cm}^{-3}$ to $1.19 \mathrm{~g} \mathrm{~cm}^{-3}$ under AFI method (Muhammad Sohail Memon et al, 2017)

Table: 2.4. Soil dry density for furrow and ridge under both methods (Muhammad Sohail Memon et al, 2017)

\begin{tabular}{|c|c|c|c|c|c|c|c|c|}
\hline \multicolumn{9}{|c|}{ Soil dry density $\mathrm{gcm}^{-3}$} \\
\hline \multirow{3}{*}{$\begin{array}{l}\text { Soil } \\
\text { depth } \\
(\mathrm{cm})\end{array}$} & \multicolumn{4}{|c|}{ Before sowing } & \multicolumn{4}{|c|}{ After harvesting } \\
\hline & \multicolumn{2}{|c|}{ Furrow } & \multicolumn{2}{|c|}{ Ridge } & \multicolumn{2}{|c|}{ Furrow } & \multicolumn{2}{|c|}{ Ridge } \\
\hline & EFI & AFI & EFI & AFI & EFI & AFI & EFI & AFI \\
\hline $0-20$ & 1.28 & $1 . .28$ & 1.25 & 1.23 & 1.32 & 1.30 & 1.22 & 1.10 \\
\hline
\end{tabular}

The total volume of irrigation water applied under AFI method (2169.70 m3 ha-1) was calculated to be half of the total irrigation water applied to EFI method (4340.91 m3 ha-1).

Table: 2.5. Irrigation water use in both methods (Muhammad Sohail Memon et al, 2017)

\begin{tabular}{cccccc}
\hline Methods & $\begin{array}{c}\text { Crop water } \\
\text { depth }(\mathrm{mm})\end{array}$ & Rainfall $(\mathrm{mm})$ & $\begin{array}{c}\text { Total water } \\
\text { depth }(\mathrm{mm})\end{array}$ & $\begin{array}{c}\text { Volume of water } \\
\text { used m }{ }^{3} / \text { sub-plot }\end{array}$ & $\begin{array}{c}\text { Water applied } \\
\left(\mathrm{m}^{3} / \mathrm{ha}^{2}\right.\end{array}$ \\
\hline EFI & 434 & 0.17 & 434.17 & 28.65 & 4340.91 \\
AFI & 434 & 0.17 & 434.17 & 14.32 & 2169.70 \\
\hline
\end{tabular}

Okra yield was recorded to be $8518 \mathrm{~kg} \mathrm{ha}^{-1}$ and $7621 \mathrm{~kg} \mathrm{ha}^{-1}$ under EFI and AFI irrigation methods. Thus, the crop yield was $10.5 \%$ more with EFI method when compared to AFI. Statistically, the effect on the yield of okra crop was found significant $(\mathrm{P}<0.05)$ under both irrigation methods (figure 2.1$)$. The comparative analysis of every furrow and alternate furrow irrigation methods showed a significant difference in the crop water productivity. As a result, the crop water productivity under EFI and AFI irrigation methods were calculated to be $1.96 \mathrm{~kg} \mathrm{~m}^{-3}$ and $3.51 \mathrm{~kg} \mathrm{~m}^{-3}$ respectively. Hence, the crop water productivity was higher under AFI when compared to EFI (M. S. Memon et al, 2017) 


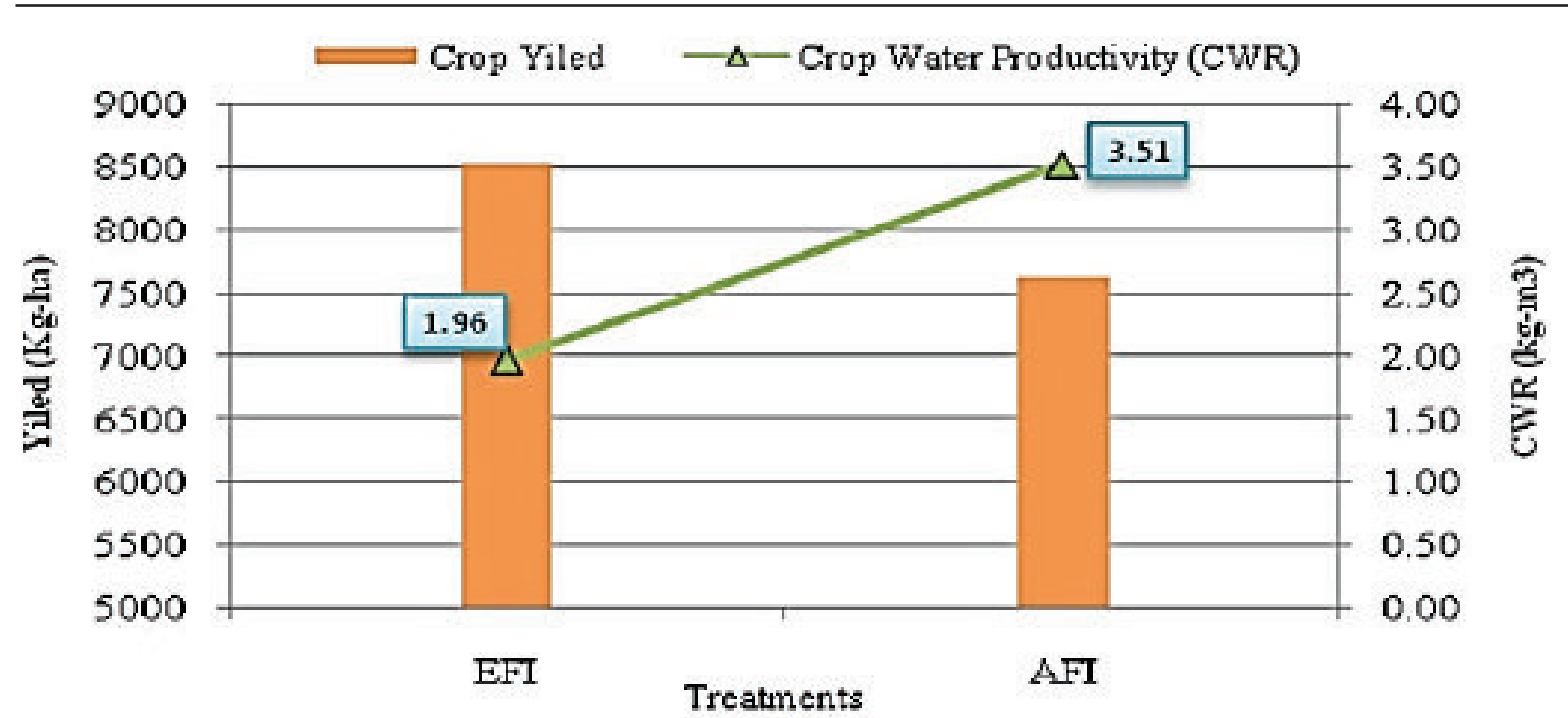

Figure: 2.1. Crop Water Productivity and yield under both methods (M. S. Memon et al, 2017)

\subsection{Comparison of Drip and Sprinkler Irrigation in Water Use and Crop Yield.}

The seasonal evapotranspiration of the crop was estimated using canopy cover measurements and reference ET data averaged from the nearest CIMIS stations (Santa Cruz, Pajaro). Cumulative crop ET was estimated to be 13.7 inches between transplanting and harvest for both zones (Table 2.6). Irrigation was scheduled in the BMP zone using crop ET and soil moisture monitoring data after the drip system was installed. A total of 12.3 inches of water were applied to the BMP zone by overhead sprinklers and drip and 12.7 inches were applied to the grower standard (GS) zone using overhead sprinklers. Rain events added an additional 2 inches of water to the crop during October and November. Irrigation efficiency was $96 \%$ for the BMP and GS zones. No run-off was measured from either management block. Soil moisture at the 8 inch and 18 inch depths of the GS block was drier than measured in the BMP block. Soil moisture tensions at the 8 inch depth was generally maintained between 20 and 60 centibars in the BMP block and between 40 and 100 centibars in the GS block. Soil moisture tensions at the 18-inch depth were also lowest in the BMP block. Estimated drainage was approximately 0.6 and 0.5 inches for the BMP and GS blocks, respectively. The low amount of drainage in both blocks would not be expected to cause large losses of $\mathrm{N}$ through nitrate leaching during the cropping cycle. Nevertheless, soil nitrate levels in the GS zone were much higher than levels measured in the BMP block during the season; and therefore nitrate was more likely to leach below the root zone in the GS block if subsequent winter rains were heavy. Highest soil nitrate-N levels were 240 ppm at the 1 foot depth in the GS block. Subsequent samples demonstrated that nitrate levels at the 2 and 3 foot depths reached 49 and 23 ppm, respectively, in the GS block. Bulk (biomass) and marketable yields were highest in the BMP zone. Yield increases in the BMP area were presumably due to less culled sprouts and greater smallsized sprouts than harvested in the GS zone (Table 2.7). The crop appeared more uniform in height and taller in the BMP zone compared with the grower standard zone. Water use efficiency (biomass/applied water) was slightly higher in the BMP block (1.0 tons/inch for the BMP treatment and 0.9 tons/inch for the GS treatment, Table 2.7). (M. Cahn and M. Buchanan, 2006)

Table: 2.6. Water use summary for Brussels sprouts in BMP and grower standard zones (inch) 2006 (M. Cahn and M. Buchanan, 2006).

\begin{tabular}{|c|c|c|c|c|c|c|}
\hline Treatment & Applied water & Crop ET & Runoff & & Drainage & Irrigation \\
\hline BMP & 14.3 & 13.7 & 0.00 & & 0.6 & 96.0 \\
\hline GS & 14.2 & 13.7 & 0.00 & & 0.5 & 96.2 \\
\hline \multicolumn{7}{|c|}{ Table: 2.7. Brussel sprout biomass and marketable yield in BMP and GS 2006 (M. Cahn and M. Buchanan, 2006} \\
\hline Treatment & $\begin{array}{c}\text { Bulk yield } \\
\text { ton/acre }\end{array}$ & $\begin{array}{c}\text { Marketable } \\
\text { yield ton/acre }\end{array}$ & $\begin{array}{l}\text { Large size } \\
(\%)\end{array}$ & $\begin{array}{c}\text { Small } \\
\text { size }(\%)\end{array}$ & Culls & $\begin{array}{l}\text { Water use efficiency } \\
\text { (ton/inch }\end{array}$ \\
\hline BMP & 14.8 & 10.7 & 28.7 & 43.6 & 28.5 & 1.0 \\
\hline GS & 13.0 & 8.8 & 31.7 & 34.7 & 37.7 & 0.9 \\
\hline
\end{tabular}

\subsection{Comparative Water Use Efficiency and Crop Productivity of Drip and Furrow Irrigation System for} Off Season Vegetables under Plastic Tunnel

The experiment was conducted under plastic tunnel at groundnut research station attock,Pakistan during 2006 2007 t0 2008-2009 to determine water consumption by three off-season vegetables irrigated through drip and furrow system, and to evaluate the comparative water use efficiency of two irrigation system in rain fed areas. 
Drip and furrow irrigation system were tested on tomato, cucumber and bell pepper in these study. A permanent tunnel of $24 \times 8 \times 3 \mathrm{~m}$ was erected. Each crop was planted on $6 * 8 \mathrm{~m}$ under drip irrigation and on $6 \times 2.7 \mathrm{~m}$ under furrow irrigation system. Water use efficiency was calculated as the ratio of total yield (Kg) to total water consumed by the crop $\left(\mathrm{m}^{3}\right)$. Each crop consumed less water under drip irrigation as compared to furrow irrigation system. Among, crops, cucumber consumed the least amount of water irrespective of irrigation system. Average water use efficiency increased by $250 \%$ for tomato, $274 \%$ for cucumber and 245 for bell pepper under drip irrigation system as compared to furrow system. On the other hand, the average fruit yield increased only by $2.05 \%$ for tomato, $3.32 \%$ for cucumber and $2.35 \%$ for bell pepper in furrow irrigation over drip irrigation. These suggested that drip irrigation has a greater scop for production of off-season vegetable especially in water scarce areas of Pakistan (M. Musa et al, 2014).

Table: 2.8. Yield increase of off-season vegetable grown under furrow over drip irrigation system (M. Musa et al, 2014).

\begin{tabular}{ccccc}
\hline Crop & Year & \multicolumn{2}{c}{ Yield $\left(\mathrm{kgha}^{-1}\right.$} & $\begin{array}{c}\text { Yield increase in furrow over drip } \\
\text { Tomato }\end{array}$ \\
\cline { 3 - 4 } & & Drip & Furrow & 3.26 \\
\cline { 3 - 4 } & $2006-07$ & 40898 & 42239 & 2.08 \\
& $2007-8$ & 41683 & 42550 & 0.82 \\
iucumber & $2008-09$ & 40690 & 41023 & 2.05 \\
& Average & 41090 & 41934 & 2.89 \\
& $2006-07$ & 33293 & 34255 & 0.29 \\
Bell pepper & $2007-8$ & 18960 & 19015 & 6.21 \\
& $2008-09$ & 24773 & 26310 & 3.32 \\
& Average & 25675 & 26527 & 2.30 \\
& $2006-07$ & 25003 & 25578 & 0.20 \\
& $2007-8$ & 19910 & 19950 & 4.76 \\
& $2008-09$ & 18330 & 19202 & 2.35 \\
\hline
\end{tabular}

Table: 2.9. Water use efficiency of off-season vegetable grown in plastic tunnel (M. Musa et al, 2014).

\begin{tabular}{|c|c|c|c|c|}
\hline \multirow{2}{*}{$\begin{array}{c}\text { Crop } \\
\text { Tomato }\end{array}$} & \multirow[t]{2}{*}{ Year } & \multicolumn{2}{|c|}{$\begin{array}{l}\text { Water use efficiency } \\
\left(\mathrm{kgm}^{-3}\right)\end{array}$} & \multirow[t]{2}{*}{$\begin{array}{l}\text { WUE increase in drip over furrow } \\
\text { irrigation system }\end{array}$} \\
\hline & & Drip & Furrow & \\
\hline & 2006-07 & 9.09 & 2.17 & 319 \\
\hline & $2007-8$ & 5.7 & 1.43 & 299 \\
\hline & 2008-09 & 5.68 & 2.21 & 157 \\
\hline \multirow[t]{4}{*}{ Cucumber } & Average & 6.5 & 1.86 & 250 \\
\hline & 2006-07 & 9.12 & 1.16 & 323 \\
\hline & $2007-8$ & 4.46 & 1.08 & 312 \\
\hline & 2008-09 & 8.48 & 3.13 & 171 \\
\hline \multirow[t]{5}{*}{ Bell pepper } & Average & 7.12 & 1.90 & 274 \\
\hline & $2006-07$ & 4.52 & 1.12 & 302 \\
\hline & $2007-8$ & 2.74 & 0.68 & 303 \\
\hline & 2008-09 & 2.35 & 0.93 & 153 \\
\hline & Average & 3.07 & 0.89 & 245 \\
\hline
\end{tabular}

\subsection{Performance of Pea under Different Irrigation Systems}

The field experiment was conducted at Precision Farming Development Centre, Central Institute of Agricultural Engineering, Bhopal on influence of different irrigation methods in three continuous years (2010-2013) on the performance pea crop. Conventional flood irrigation, micro sprinkler and drip irrigation systems were adopted as three treatments and with seven replications in each treatment in the study. Pea (Arkel variety) crop was sown at a spacing of 45 X $10 \mathrm{~cm}$. During the period of experiment flood irrigation were applied on weekly basis and micro irrigation and drip irrigation systems were operated every third day to meet the crop water requirement. The total quantity of water applied in flood, drip irrigation and micro sprinkler systems were 387.5, 244.7 and $273.5 \mathrm{~mm}$ respectively. Performance of different irrigation systems in pea was evaluated continuously for three years. The average values of the crop growth parameters collected for the crop in each treatment for the three years were pooled and the average values are presented in Table 4 . The plant growth parameters such as average plant height was significantly higher under micro sprinkler irrigation $(59.7 \mathrm{~cm})$ followed by drip $(55.8 \mathrm{~cm})$ irrigation. Average number of branches per plant were higher in micro sprinkler irrigated pea (3.4) followed by drip irrigated (2.8) and lowest in conventional irrigated pea crop. Average numbers of pods per plant (18.7) were significantly higher 
under micro sprinkler irrigation followed by drip irrigation (14.8) and conventional irrigation (12.6) (K.V. Ramana Rao et al, 2017)

Table: 2.10. Growth and yield parameters of pea under different irrigation (K.V. Ramana Rao et al, 2017)

\begin{tabular}{llllll}
\hline Treatments & $\begin{array}{l}\text { Average plant } \\
\text { height }(\mathrm{cm})\end{array}$ & $\begin{array}{l}\text { Average no. of } \\
\text { branches/plant }\end{array}$ & $\begin{array}{l}\text { Average no. of } \\
\text { pods/plant }\end{array}$ & $\begin{array}{l}\text { average } \\
\text { yield } \\
\text { (ton/ha) }\end{array}$ & $\begin{array}{l}\text { Increase in yield over } \\
\text { conventional irrigation }\end{array}$ \\
\hline TI & 52.4 & 2.1 & 12.6 & 5.87 & - \\
T2 & 55.8 & 2.8 & 14.8 & 7.74 & 31.8 \\
T3 & 59.7 & 3.4 & 18.7 & 9.81 & 67.1 \\
\hline
\end{tabular}

The study results indicated that the drip and micro sprinkler irrigation systems saved 38 and 26 percent of water over conventional practice (Table 5). The water productivity is the ratio between the productions per unit of water applied. Though, the percentage of water saving under micro sprinkler irrigation is less than the drip irrigation, the water productivity under micro sprinkler $(2.65 \mathrm{~kg} / \mathrm{m} 3)$ was higher than under the drip $(2.49 \mathrm{~kg} / \mathrm{m} 3)$ irrigation and significantly higher than under conventional irrigation system $(1.17 \mathrm{~kg} / \mathrm{m} 3)$, According to (Bernstein, 1975) sprinkler irrigation often allow much more efficient use of water and a reduction in deep percolation losses and increase the potential of crop yield. The highest average yield was obtained under micro sprinkler irrigated pea with $(9.81 \mathrm{t} / \mathrm{ha})$ followed by drip irrigation with $(7.74 \mathrm{t} / \mathrm{ha})$.

Table: 2.11. Water productivity and crop yield (K.V. Ramana Rao et al, 2017)

\begin{tabular}{cccc}
\hline Treatment & $\begin{array}{c}\text { Average yield \% } \\
\text { (ton/ha) }\end{array}$ & $\begin{array}{c}\text { Water saving over conventional } \\
\text { irrigation }\end{array}$ & $\begin{array}{c}\text { Water productivity } \\
\left(\mathrm{kg} / \mathrm{m}^{3}\right)\end{array}$ \\
\hline TI & 5.87 & - & 1.17 \\
T2 & 7.74 & 37 & 2.49 \\
T3 & 9.81 & 29 & 2.65 \\
\hline
\end{tabular}

\subsection{Deficit Irrigation and Irrigation Methods as on-Farm Strategies to Maximize Crop Water Productivity} in Dry Areas

On farm strategies is very important for crop yield as well as water use productivity. The researcher investigates the effect of deficit irrigation and irrigation methods as on-farm strategies to maximize crop water productivity in dry areas. In the investigation the researcher carried out an in-situ field experiment on two types of irrigation methods ( SSDI and SDI) and three irrigation levels was conducted in a sandy loam soil located at King Saud University, Riyadh, Saudi Arabia in 2015 and 2016. This investigation was to investigate the effects of different irrigation methods on physiological and yield responses of tomato crops under water shortage conditions. The tested irrigation methods were surface drip irrigation (SDI) and subsurface drip irrigation (SSDI) systems. Irrigation treatments consisted of three strategies these are plants were irrigated with a water depth of $100 \%$ of the full irrigation supply, plants were irrigated with a water depth of $80 \%$ of the full irrigation supply and plants were irrigated with a water depth of $60 \%$ of the full irrigation supply. The researcher results indicated that water shortage significantly affected yield and quality response for each season. Over a 2-year average, yield increase was greatest in $\mathrm{T}_{1}$-SSDI followed by $\mathrm{T}_{2}$-SSDI and then $\mathrm{T}_{1}$-SDI. The yield response factor was 0.95 and 1.05 for SSDI and SDI, respectively. The highest water use efficiency values were obtained in T2-SSDI $\left(16.3 \mathrm{~kg} \mathrm{~m}^{-3}\right)$ and $\mathrm{T}_{1}$-SSDI (15.6 $\left.\mathrm{kg} \mathrm{m}^{-3}\right)$, and the lowest ones, those estimated in T1-SDI $\left(10.9 \mathrm{~kg} \mathrm{~m}^{-3}\right)$ and $\mathrm{T}_{3}$-SDI $\left(9.5 \mathrm{~kg} \mathrm{~m}^{-3}\right)$ (Hussein M. et al, 2018)

Table: 2.12. Average fruit yield components for tomato plants using different irrigation strategies (Hussein M. et al, 2018)

\begin{tabular}{llllll}
\hline Irrigation system & Treatment & $\begin{array}{l}\text { Early yield } \\
\left(\text { tonha }^{-1}\right)\end{array}$ & $\begin{array}{l}\text { Total yield } \\
\left(\text { tonha }^{-1}\right)\end{array}$ & $\begin{array}{l}\text { Fruit weight } \\
(\mathrm{g})\end{array}$ & Fruit number/plant \\
\hline Subsurface (SSDI) & $\mathrm{T}_{1}$ & 53.46 & 88.75 & 149.23 & 31.46 \\
& $\mathrm{~T}_{2}$ & 45.94 & 74.94 & 138.61 & 26.92 \\
& $\mathrm{~T}_{3}$ & 38.56 & 55.25 & 91.57 & 23.61 \\
Drip (SDI) & $\mathrm{T}_{1}$ & 47.27 & 69.60 & 140.91 & 28.91 \\
& $\mathrm{~T}^{2}$ & 36.93 & 58.01 & 129.50 & 25.05 \\
& $\mathrm{~T}_{3}$ & 29.64 & 39.85 & 84.76 & 21.48 \\
\hline
\end{tabular}




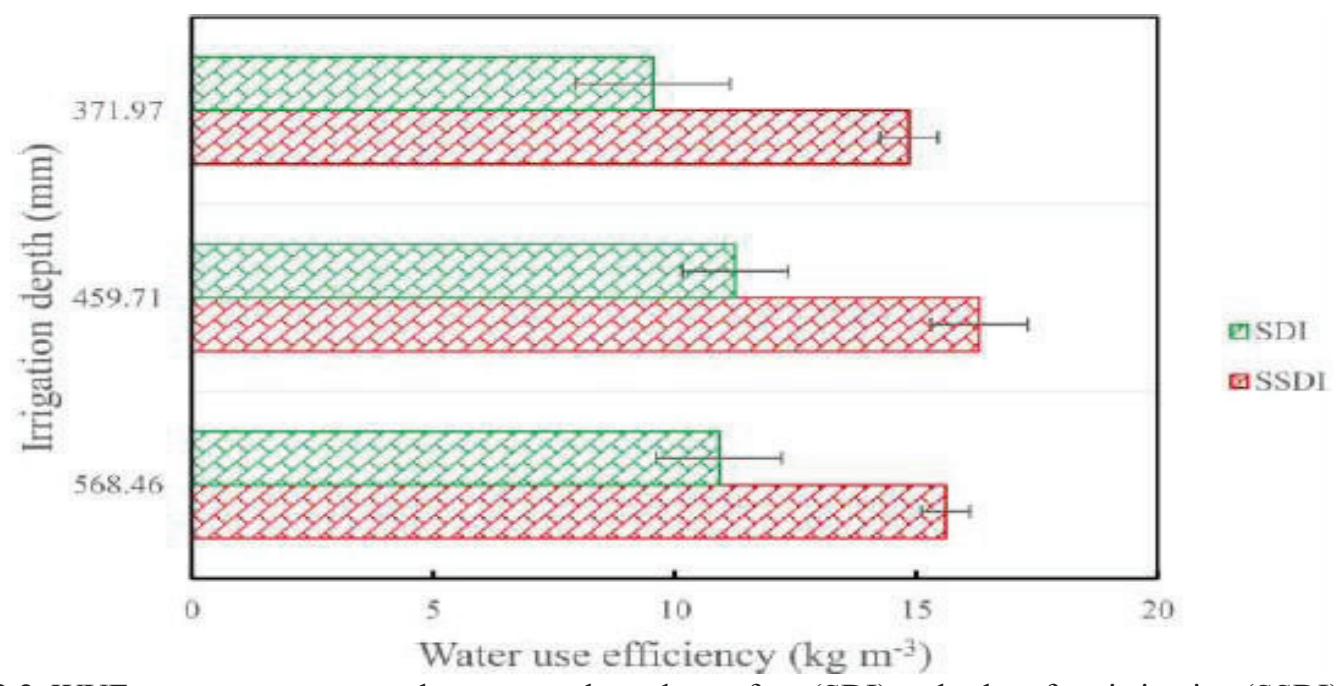

Figure: 2.2. WUE responses to seasonal water supply under surface (SDI) and subsurface irrigation (SSDI) systems (Hussein M. et al, 2018)

\subsection{Maximizing Water Productivity and Yields of wheat Based on Drip Irrigation Systems in Clay loam Soil}

In the work I have been indicate my review how maximize productivity by increasing water productivity in clay loam soil. In this investigation the researcher investigates maximizing water productivity is one of the most important police in developing countries. Therefore, this study was to estimate the wheat yield response to drip irrigation systems and the attributed water use efficiency and saving water indices under clay loam soil conditions of semi tropical regions. A field experiments was conducted at the field of Jawaharlal Nehru Krishi Vishwa Vidyalaya (JNKVV), Jabalpur, Madhya Pradesh, India, during the rabi seasons of 2011-12 to study the effect of drip irrigation on water productivity and yield attributes of wheat crop. The climate of the study area was semi tropical and annual temperature was $25.7^{\circ} \mathrm{C}$ and average annual rainfall of the area was $1300 \mathrm{~mm}$. the soil of the study area was clay loam soil with contain clay $39.52 \%$, silt $27.82 \%$ and loam $32.65 \%$. Results revealed that water saving of about $9.7 \%$ higher in case of drip irrigation compared with the solid-set sprinkler irrigation system. The wheat grain yield and 1000 grain wt. (test wt.), data indicated that in drip irrigation grain yield was $12.14 \%$ and test weight was $17.86 \%$ more than the sprinkler irrigated wheat. However there was a slightly reduction of $2.08 \%$ in biological yield. This may be due to the wheat plants had exposed to higher water stress during the growing stages. Data also revealed that water productivity of drip irrigated wheat was $21.76 \%$ more than the sprinkler irrigated wheat. It can be concluded that the alternative irrigation system (drip irrigation) has an effective way for irrigating intensive field crops, but more studies have to be conducted under similar field conditions (Sanjay Singh Chouhan et al, 2014)

Table: 2.13 . The yield attributes characters and water productivity of wheat crop under drip and sprinkler irrigation (Sanjay Singh Chouhan et al, 2014)

\begin{tabular}{lcc}
\hline Parameters & \multicolumn{2}{c}{ Irrigation method } \\
\cline { 2 - 3 } & Drip & Sprinkler \\
\hline Biological yield $\left(\mathrm{qha}^{-1}\right)$ & 85.32 & 87.10 \\
Grain yield $\left(\mathrm{qha}^{-1}\right)$ & 42.95 & 38.30 \\
Straw yield $\left(\mathrm{qha}^{-1}\right)$ & 42.37 & 48.80 \\
1000-grain wt. $(\mathrm{gm})$ & 38.66 & 32.80 \\
Grain - straw ratio & 1.01 & 0.78 \\
Total irrigation water applied $(\mathrm{cm})$ & 35.00 & 38.00 \\
Water productivity $\left(\mathrm{kgha}^{-1} \mathrm{~cm}\right.$ & 122.71 & 100.78 \\
\hline
\end{tabular}

\subsection{Effects of Drip Irrigation Water Amount on Crop Yield, Productivity and Efficiency of Water Use in Desert Regions}

Among the factors that affect the water use efficiency and yield production method of water application is one factor. From here I have been review effects of drip irrigation water amount on crop yield, productivity and efficiency of water use in desert regions. Drip irrigation may apply in subsurface or surface drip irrigation. In these research the investigator conducted subsurface drip irrigation (SDI) system was used to investigate the appropriate irrigation water schedules in open fields and greenhouse for different vegetables. The study investigated and analyzed different pipeline material, spacing between emitters, and soil profile. Also, it investigates the effects of 
soil type and climate on water consumption. Two (2) Enviroscan sensors were installed to measure the soil moisture. Also, two (2) weather stations were installed to measure the climate parameters. The crop evapotranspiration and the amount of irrigation water were determined using software based on Penman-Monteith approach. The FAO guidelines were used as a reference. The obtained climate and crop growth parameters were analyzed and the crop water use was determined. These determined values were used to develop an appropriate schedule for water use and for crop production in order to ensure sustainable water management. The results revealed that all plants morphological characters increased significantly using Eolose pipelines than T-tape and Tuporex, respectively. The reduction in plant growth is interpreted by the irregularity of water distribution in the soil profile and the water stress causing losses in tissue water which reduce pressure in the cell. The decreases in enlargement and division of cells decrease leaf area and hence the effectiveness of photosynthetic surface. The fresh yields average for tomato are 16243, 17717, 16866 and $16809 \mathrm{~kg} /$ fed under surface drip system with GR emitter and SDI system using Eolose, T tape and Tuporex emitters, respectively in open field. While they are equal to 12832,13762 and $12971 \mathrm{~kg} /$ fed for pepper under surface drip with GR emitter and SDI system for Eolose and Tuporex emitters, respectively. For each vegetable type the higher productivity is obtained for SDI with Eolose, T-tape then Tuporex pipelines, whereas it shows the lower yield using surface dripping GR. demonstrate the different productivity elements (i.e., weight of ten fruits, and weight of largest ones) that are directly related to the total fresh yield per feddan. The total water consumptive use values of tomato and pepper using GR drip irrigation systems are 1325.02 and $2826.73 \mathrm{~m} 3 / \mathrm{fed}$, respectively. While the SDI water consumptive uses are (1662.07 and1633.72), (1367.27 and 1352.82), and (2923.54 and $2870.87 \mathrm{~m} 3 /$ fed) using Eolose, T-tape and Tuporex, respectively. These concluding results demonstrate that the highest values of water consumptive use were obtained with Eolose followed by T-tape and Tuporex, respectively. SDI water consumptive use values are relatively higher than that of DI using GR pipelines, which may be interpreted by the increase of evaporation from soil for DI over SDI systems. Water use efficiency in open field increased considerably by $11.73 \%, 7.11 \%$ and $4.52 \%$ for tomato referred to the DI GR system. For greenhouse, the increment percentage for pepper was $16.42 \%$ and $10.80 \%$ for Eolose and Tuporex compared to GR drip system, respectively (H. K. Soussa, 2010).

\subsection{Water Use Efficiency and Yield of Maize Crop under Different Irrigation Methods}

In these review what we understand is what were effect of different irrigation methods on water use efficiency and yield of maize crop. In these case the investigator carried out a field experiment was conducted to evaluate the effect of three different irrigation water application including ridge planting $\left(\mathrm{T}_{1}\right)$, planting under furrow irrigation $\left(\mathrm{T}_{2}\right)$ and line planting under basin irrigation $\left(\mathrm{T}_{3}\right)$ on soil physical properties, water use efficiency, plant growth parameters and yield of maize crop is analyzed. The water requirement for maize crop was determined using CROPWAT 8.0 Model. Statistical analysis showed that the average values of the dry bulk density, soil porosity, plant height, crop yield and water use efficiency were significant $(P<0.05)$, while other parameters such as stem girth, number of leaves per plant, number of cobs per plant and 1000-grain weight were no significant $(P>0.05)$ under all treatments. The results presented that the total volume of water applied to crop under $\mathrm{T}_{1}$ was lower (3632), compared to $\mathrm{T}_{2}$ (3936) and $\mathrm{T}_{3}$ (5904). The results of plant growth parameters are presented in table below 2.14 the average plant height was $159 \mathrm{~cm}, 151 \mathrm{~cm}$ and $150 \mathrm{~cm}$, the stem girth of plant was $1.89 \mathrm{~cm}, 1.85 \mathrm{~cm}$ and $1.97, \mathrm{~cm}$ the numbers of leaves per plant was $10.8,10.8$ and 10.47, and number of cobs per plant was 1.6, 1.5 and 1.46 under T1, T2 and T3, respectively. These results indicate that average plant height, number of leaves per plant and number of cobs per plant were higher under $T_{1}$ compared to $T_{2}$ and $T_{3}$ treatments. However, the stem girth of plant was higher under $T_{3}$, followed by $T_{1}$ and $T_{2}$. The results of weight of 1000-grains and yield of crop are presented in Figures 8 and 9. The weight of 1000-grains was 300, 167 and 267 under $T_{1}, T_{2}$ and $T_{3}$, respectively. Yield of crop was 4268, 3298 and $2924 \mathrm{~kg}$ ha-1 under $\mathrm{T}_{1}, \mathrm{~T}_{2}$ and $\mathrm{T} 3$, respectively. The results showed that $\mathrm{T}_{1}$ produced more 1000-grains weight, followed by $\mathrm{T}_{2}$ and $\mathrm{T}_{3}$. Similarly the yield of crop was higher under $\mathrm{T}_{1}$ than $\mathrm{T}_{2}$ and $\mathrm{T}_{3}$. The average water use efficiency was $1.17,0.84$ and 0.50 under $T_{1}, T_{2}$ and $T_{3}$ table below. It is evident that water use efficiency (WUE) was higher under $\mathrm{T}_{1}$ compared to $\mathrm{T}_{2}$ and $\mathrm{T}_{3}$ treatments ( $\mathrm{S}$. M. Kori et at, 2017)

Table: 2.14. Plant growth and yield parameter and water use efficiency (S. M. Kori et at, 2017)

\begin{tabular}{llllllll}
\hline Treatment & $\begin{array}{l}\text { Plant } \\
\text { height } \\
(\mathrm{cm})\end{array}$ & $\begin{array}{l}\text { Stem girth } \\
(\mathrm{cm})\end{array}$ & $\begin{array}{l}\text { Number of } \\
\text { leaves/ } \\
\text { plant }\end{array}$ & $\begin{array}{l}\text { Numbers of } \\
\text { cobs /plant }\end{array}$ & $\begin{array}{l}1000- \\
\text { grains } \\
\text { weight }(\mathrm{g})\end{array}$ & $\begin{array}{l}\text { Crop yield } \\
(\mathrm{kgha})\end{array}$ & $\begin{array}{l}\text { WUE } \\
(\mathrm{m} 3 \mathrm{ha}-1)\end{array}$ \\
\hline $\mathrm{T}_{1}$ & 159 & 1.89 & 10.8 & 1.6 & 300 & 4268 & 1.17 \\
$\mathrm{~T}_{2}$ & 151 & 1.85 & 10.8 & 1.5 & 167 & 3298 & 0.84 \\
$\mathrm{~T}_{3}$ & 150 & 1.97 & 10.47 & 1.46 & 267 & 2924 & 0.5 \\
\hline
\end{tabular}

\section{Conclusion}

In general from the previous study the effect of different irrigation method on water use efficiency, yield productivity and nitrogen application (yield and water productivity of vegetable production under drip and furrow irrigation, effect of different irrigation intervals on water saving, water productivity and grain yield of maize under 
the double ridge-furrow, effect of irrigation methods and plastic mulch on yield and crop water productivity of okra, comparison of drip and sprinkler irrigation in water use and crop yield, comparative water use efficiency and crop productivity of drip and furrow irrigation system for off season vegetables under plastic tunnel, performance of pea under different irrigation systems, deficit irrigation and irrigation methods as on-farm strategies to maximize crop water productivity in dry areas, maximizing water productivity and yields of wheat based on drip irrigation systems in clay loam soil, effects of drip irrigation water amount on crop yield, productivity and efficiency of water use in desert regions) are investigated. From these investigation different conclusion is raised depend on deferent parameters and irrigation method. From the study the parameter taken under consideration are crop morphological characters (plant height, stem girth, cobs, fruit per plant, and leaves per plant e.tc), yield (kgha-1), water productivity $\left(\mathrm{kgha}^{-1}\right)$ and water use efficiency. The study applies different irrigation method to compare its crop morphological characters (plant height, stem girth, cobs, fruit per plant, and leaves per plant e.tc), yield (kgha ${ }^{-}$ ${ }^{1}$ ), water productivity $\left(\mathrm{kgha}^{-1}\right)$ and water use efficiency these irrigation method are convention surface irrigation, furrow irrigation, double ridge furrow irrigation, sprinkler irrigation, surface drip irrigation (SDI), subsurface drip irrigation (SSDI) and drip irrigation under different pipeline.

\section{Recommendation}

In these literature I have been recommend that first, Yield and growth parameters of the crop depend on the fertility of the soil, chemical fertilizer and physical properties of the rather than irrigation method, therefore, the researchers should be consider these factors. Secondly, Water productivity and water use efficiency also depend on soil physical properties, environmental condition, appropriate irrigation scheduling, estimation of crop water requirement and conveyance system of irrigation and cropping season in addition to irrigation method.

\section{Reference}

Abd El-Halim Awad Abd El-Halim AND Usama Abd El-Hameid Abd El-Razek . (2013): Effect of different irrigation intervals on water saving, water productivity and grain yield of maize (Zea mays L.) under the double ridge-furrow planting technique, Archives of Agronomy and Soil Science.

Bittelli, Marco. (2010). Measuring Soil Water Potential for Water Management in Agriculture. A Review Sustainability 2, no. 5, (1226-51.

B. K. JHA, S. S. MALI, S. K. NAIK \& T. SENGUPTA. (2017). Yield, water productivity and economics of vegetableproduction under drip and furrow irrigation in eastern plateau and hill region of indiaInternational Journal of Agricultural Science and Research (IJASR), Vol. 7, Issue 3

Brady, Nyle C., and Weil, Ray R. (2010) Elements of the Nature and Properties of Soils. Third Edition . Upper Saddle River, N.J: Prentice Hall.

H. K. Soussa. (2010). Effects of drip irrigation water amount on crop yield, productivity and efficiency of water use in desert regions in Egypt. Nile Basin Water Science\& Engineering Journal, Vol.3, Issue2.

Hussein M. Al-Ghobari and Ahmed Z. Dewidar. (2018).Deficit irrigation and irrigation methods as on-farm strategies to maximize crop water productivity in dry areas. Journal of water and climate change.

Knox, J. W., M. G. Kay, and E. K. Weatherhead. (2012). Water Regulation, Crop Production, and Agricultural Water Management-Understanding Farmer Perspectives on Irrigation Efficiency. Agricultural Water Management, Irrigation efficiency and productivity: scales, systems and science, 108, 3-8.

K.V. Ramana Rao, Suchi Gangwar, Arpna Bajpai, Ravish Keshri, Lavesh Chourasia and Kumar Soni. (2017). Performance of pea under different irrigation systems. Legume Research, 40 (3).

Muhammad Sohail Memon, Altaf Ali Siyal, Ji Changying, Ahmed Ali Tagar, Shamim Ara, Shakeel Ahmed Soomro, Khadimullah, Fahim Ullah and Noreena Memon. Effect of irrigation methods and plastic mulch on yield and crop water productivity of okra. (2017). Journal of Basic \& Applied Sciences, 13, 616-621.

M. Cahn and M. Buchanan. (2006).Comparison of drip and sprinkler irrigation in Brussels sprouts: water use, nitrogen, and crop yield.

M. Musa, M. Iqbal, M.Tariq, F.H.Sahi, N.M.Cheema,F.N.Jahan. (2014). Comparative water use efficiency of drip and furrow irrigation system for off-season vegetables under plastic tunnel. SAARCJ.Agri, 12(1).

Rosegrant, M. W. (1997). Water resources in the twenty-first century: Challenges and implications for action. (Vol. 20), Intl Food Policy Res Inst.

Sanjay Singh Chouhan, Dr. M. K. Awasthi and Dr. R. K. Nema. (2014). Maximizing water productivity and yields of wheat based on drip irrigation systems in clay loam soil.International Journal of Engineering Research \& Technology (IJERT), Vol. 3 Issue 7.

Sauer, Timm, Petr Havlík, Uwe A. Schneider, Erwin Schmid, Georg Kindermann, and Michael Obersteiner. (2010).Agriculture and Resource Availability in a Changing World: The Role of Irrigation. Water Resources Research 46, no. 6.

S. M. Kori1, C. Soothar, A. L. Qureshi and S. H. Ashrafani.(2017). Effect of different irrigation methods on water use efficiency and yield of maize crop .Pak. J. Agri., Agril. Engg., Vet. Sci, 33 (1). 